\title{
Cardio-pulmonary resuscitation challenges in selected Botswana hospitals: Nurse managers' views
}

\begin{tabular}{|c|c|}
\hline \multicolumn{2}{|c|}{$\begin{array}{l}\text { Authors: } \\
\text { Lakshmi Rajeswaran }{ }^{1,2} \\
\text { Valerie J. Ehlers }{ }^{2}\end{array}$} \\
\hline \multicolumn{2}{|c|}{$\begin{array}{l}\text { Affiliations: } \\
{ }^{1} \text { Department of Nursing, } \\
\text { University of Botswana, } \\
\text { Botswana }\end{array}$} \\
\hline \multicolumn{2}{|c|}{$\begin{array}{l}{ }^{2} \text { Department of Health } \\
\text { Studies, University of South } \\
\text { Africa, South Africa }\end{array}$} \\
\hline \multicolumn{2}{|c|}{$\begin{array}{l}\text { Correspondence to: } \\
\text { Valerie Ehlers }\end{array}$} \\
\hline \multicolumn{2}{|c|}{$\begin{array}{l}\text { Email: } \\
\text { ehlervj@unisa.ac.za }\end{array}$} \\
\hline \multicolumn{2}{|c|}{$\begin{array}{l}\text { Postal address: } \\
\text { PO Box } 65075 \text {, Erasmusrand } \\
\text { 0165, South Africa }\end{array}$} \\
\hline \multicolumn{2}{|c|}{$\begin{array}{l}\text { Dates: } \\
\text { Received: } 03 \text { Feb. } 2012 \\
\text { Accepted: } 13 \text { Feb. } 2013 \\
\text { Published: } 07 \text { May } 2013\end{array}$} \\
\hline \multicolumn{2}{|c|}{$\begin{array}{l}\text { How to cite this article: } \\
\text { Rajeswaran, L. \& Ehlers, V.J., } \\
\text { 2013, 'Cardio-pulmonary } \\
\text { resuscitation challenges in } \\
\text { selected Botswana hospitals: } \\
\text { Nurse managers' views', } \\
\text { Health SA Gesondheid 18(1), } \\
\text { Art. \#672, } 8 \text { pages. } \\
\text { http://dx.doi.org/10.4102/ } \\
\text { hsag.v18i1.672 }\end{array}$} \\
\hline \multicolumn{2}{|c|}{$\begin{array}{l}\text { Copyright: } \\
\text { (C) 2013. The Authors. } \\
\text { Licensee: AOSIS } \\
\text { OpenJournals. This work } \\
\text { is licensed under the } \\
\text { Creative Commons } \\
\text { Attribution License. }\end{array}$} \\
\hline \multicolumn{2}{|l|}{ Read online: } \\
\hline 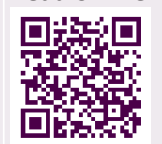 & $\begin{array}{l}\text { Scan this QR } \\
\text { code with your } \\
\text { smart phone or } \\
\text { mobile device } \\
\text { to read online. }\end{array}$ \\
\hline
\end{tabular}

Road traffic accident victims, as well as persons experiencing cardiac and other medical emergencies, might lose their lives due to the non-availability of trained personnel to provide effective cardio-pulmonary resuscitation (CPR) with functional equipment and adequate resources. The objectives of the study were to identify unit managers' perceptions about challenges encountered when performing CPR interventions in the two referral public hospitals in Botswana. These results could be used to recommend more effective CPR strategies for Botswana's hospitals. Interviews, comprising two quantitative sections with closed ended questions and one qualitative section with semi-structured questions, were conducted with 22 unit managers. The quantitative data indicated that all unit managers had at least eight years' nursing experience, and could identify CPR shortcomings in their hospitals. Only one interviewee had never performed CPR. The qualitative data analysis revealed that the hospital units sometimes had too few staff members and did not have fully equipped emergency trolleys and/or equipment. No CPR teams and no CPR policies and guidelines existed. Nurses and doctors reportedly lacked CPR knowledge and skills. No debriefing services were provided after CPR encounters. The participating hospitals should address the following challenges that might affect CPR outcomes: shortages of staff, overpopulation of hospital units, shortcomings of the emergency trolleys and CPR equipment, absence of CPR policies and guidelines, absence of CPR teams, limited CPR competencies of doctors and nurses and the lack of debriefing sessions after CPR attempts.

Die slagoffers van padongelukke, asook persone wat hart- en ander mediese noodtoestande ervaar, kan hulle lewens verloor omdat daar nie opgeleide personeel met funksionele toerusting en voldoende hulpbronne beskikbaar is om effektiewe kardiopulmonale resussitasie (KPR) te doen nie. Die studie het ten doel gehad om eenheidsbestuurders se persepsies te bepaal oor uitdagings wat hulle in die gesig staan wanneer KPR-tussentredes plaasvind in die twee openbare hospitale in Botswana wat as verwysingshospitale dien. Die bevindings kan gebruik word om effektiewer KPR-strategieë vir Botswana se hospitale aan te beveel. Onderhoude bestaande uit twee kwantitatiewe afdelings met geslote vrae en een kwalitatiewe afdeling met semi-gestruktureerde vrae is met 22 eenheidsbestuurders gevoer. Die kwantitatiewe data het aangedui dat alle eenheidsbestuurders minstens agt jaar se verpleegervaring het en dat hulle die tekortkomings sover dit KPR in hulle hospitale aangaan, kon identifiseer. Slegs een persoon het nog nooit KPR toegepas nie. Die ontleding van die kwalitatiewe data dui daarop dat hospitaaleenhede soms te min personeel het en dat hulle nie ten volle toegeruste noodtrollies en/of toerusting het nie. Geen KPR-spanne en geen KPR-beleid of -riglyne bestaan nie. Verpleegkundiges en dokters het volgens die onderhoude 'n gebrek aan KPR-kennis en -vaardighede. Geen ontlontingsdienste is na KPR-voorvalle vir die personeel beskikbaar nie. Die deelnemende hospitale behoort die uitdagings aan te spreek wat KPR-uitkomste kan beinvloed. Hierdie uitdagings sluit in personeeltekorte, oorbesetting in hospitaaleenhede, tekortkomings in die noodtrollies en toerusting, die gebrek aan KPR-beleid en -riglyne, die afwesigheid van KPR-spanne, dokters en verpleegsters se beperkte KPR-vaardighede en die feit dat ontlontingsdienste nie na KPR-pogings vir personeellede beskikbaar is nie.

\section{Introduction}

In Botswana, nurses provide primary, secondary, and tertiary health services throughout the country. Medical doctors and nurses are available in the 17 primary hospitals, 14 district hospitals and three referral hospitals, one of which is a psychiatric hospital (Republic of Botswana 2006:2).

Cardio-pulmonary resuscitation (CPR) consists of steps undertaken by skilled practitioners in the event of cardiac and/or respiratory arrest (Davies \& Gould 2000:400). It is a combination resuscitation attempt of artificial breathing, supplying oxygen to the lungs, and external chest compressions to re-establish cardiac function, blood circulation and respiration (Handley et al. 2005:S7). 
Survival rates for cardiac arrest can be improved by regular CPR training and available emergency equipment, including defibrillators (Pottle \& Brant 2000:50). The research question that arose was: 'How do unit managers rate the CPR training of nurses, the supply and maintenance of emergency equipment and resources, and emergency policies and procedures in the two general referral government hospitals in Botswana?'

\section{Problem statement}

In Botswana $1 \%$ of adult mortalities are attributed to road accidents and $4 \%$ to atherosclerotic disease (ischemic heart disease and cerebro vascular accidents combined). According to Botswana's road traffic safety annual report, 18136 persons were involved in car accidents, $3 \%(n=532)$ were killed and $43 \%(n=7840)$ were injured during 2004 (Central Statistics Office 2005). Some of these 7840 persons, as well as an unknown number of adults and children encountering other medical, accident and/or surgical emergencies, might have required CPR interventions. In Botswana, nurses frequently have to supply CPR services. Thus many patients' lives and well-being might depend on nurses' CPR knowledge and skills.

Out of 508 death records audited during 2008 by the first author in the two referral hospitals, 96 (19\%) CPR attempts were reported. This low rate of CPR attempts could be due to inadequate CPR knowledge and skills among registered nurses and/or the shortage of CPR supplies and/or the absence of clear policies.

\section{Aim of the study}

The aim of the study was to identify unit managers' perceptions about possible challenges posed by nurses' $\mathrm{CPR}$ training and by the quality and quantity of emergency equipment to provide effective CPR interventions. Based on the findings, recommendations could be made for improving these situations and saving more persons' lives in Botswana.

\section{Research objectives}

The objectives of the study were to identify nurses managers' perceptions about the following potential CPR challenges in the two participating hospitals:

- Nurses' CPR training, competencies and knowledge.

- Adequacy of CPR emergency trolleys, equipment and resources.

- CPR teams, policies and procedures.

- Debriefing services after after CPR interventions.

\section{Definitions of key concepts}

Cardiopulmonary resuscitation (CPR) is an emergency procedure performed to restore a person's cardiac function, blood circulation and respiration.

A registered nurse is someone who has completed a basic three-year nursing education programme and is registered with the Nursing and Midwifery Council of Botswana.
A unit manager is a registered nurse with considerable clinical experience who occupies a managerial position in a specific unit of one of the two participating hospitals (In Botswana the term 'nurse manager' is used).

\section{Research method and design}

A mixed quantitative and qualitative descriptive design was adopted to obtain information about unit managers' perceptions concerning CPR challenges in their hospitals. Individual interviews were conducted with 22 unit managers. The mixed methodology (sections 1 and 2 of the interview schedule comprised quantitative closed ended questions, but section 3 contained semi-structured questions which were analysed qualitatively) was used to generate information about CPR challenges.

\section{Research setting}

Two referral hospitals in Botswana, each with 11 wards, participated in the study since their unit managers respond to medical, surgical, obstetric and trauma cases.

\section{Procedure}

The target population comprised both hospitals' unit managers from male and female medical, surgical and orthopaedic wards as well as from the intensive care units (ICUs), gynaecology, maternity, paediatric, accident and emergency (A\&E) sections. Non-probability purposive sampling was used to select participants. Unit managers with at least 12 months' full time experience as unit managers could be interviewed, if they agreed. The sample comprised 22 such unit managers. Unit managers are knowledgeable about CPR challenges and were deemed to be appropriate informants about CPR challenges.

\section{Data collection instrument}

An interview schedule with three sections was designed, based on the literature review. The interview schedule's first section's closed-ended questions requested biographic information, the second section's closed-ended questions pertained to CPR aspects in specific units, while the third section's semi-structured questions attempted to identify unit managers' perceived CPR challenges in their units.

The instrument was pre-tested by interviewing two unit managers who met the inclusive criteria but who were excluded from participating in the actual study. Pretesting indicated that each interview lasted approximately 45 minutes and the unit managers understood all questions.

\section{Data collection procedure}

Data were collected during June 2008 in both hospitals. Prior appointments were made with the unit managers. Individual audio-taped interviews lasting 30 minutes -40 minutes were conducted with the nurse mangers during their on-duty time in private rooms adjacent to their wards, when it suited the 
participants. Each participant's reactions, body language and non-verbal behaviour were recorded as field notes.

\section{Data analysis}

The closed-ended questions from sections one and two were analysed by using the Microsoft Word program. The qualitative data of section three were analysed using Tesch's (in Creswell 2003:192) open coding method of analysing descriptive data. Transcripts were read and reread and the audiotapes were listened to repeatedly in order to become acquainted with the data as a whole. Then, after sifting of data according to the perceived relevance to the aim of the study, they were coded to develop categories and subcategories. An independent coder and the researcher's categories were compared and discussed until consensus was reached.

\section{Ethical considerations}

Permission to conduct interviews with the unit managers was granted by Botswana's Ministry of Health, and by the participating hospitals' managers, after the research proposal had been accepted by the Ethics and Research Committee of the Department of Health Studies, University of South Africa.

Each manager signed a consent form, indicating that he/ she participated voluntarily and could refuse to answer any specific question or terminate the interview at any stage, and agreed that the interview could be audio-taped. Anonymity was guaranteed as no interviewee's name was mentioned in any document. Confidentiality was ensured as the audiotapes, field notes and transcriptions of the interviews were kept locked up. Only the researchers, a statistician and a data analyst had access to the raw data, to be destroyed subsequent to the acceptance of the research report.

\section{Trustworthiness}

Trustworthiness exists when the findings of a qualitative study represent reality, and are worth paying attention to because they can be trusted. Guba's model (Lincoln \& Guba 1985) of trustworthiness of qualitative research comprises four criteria for trustworthiness, namely credibility, transferability, dependability and confirmability (Stommel \& Wills 2004:289).

Dependability refers to the stability of information patterns over time or on different occasions (Stommel \& Wills 2004:288). An independent coder, an experienced qualitative researcher, analysed the data, independently from the researchers' analyses. After discussions, agreement was reached about the categories and subcategories that emerged from the data. 'Member checking' was done with the participants to ensure that the recorded information reflected their experienced CPR challenges. Field notes compiled during each interview were compared with the audio recordings, enhancing the dependability of the findings.

Credibility refers to activities that increase the trustworthiness of the findings (Stommel \& Wills 2004:289).
The first author met the unit managers during a previous study and established rapport with them. She requested their participation personally, made appointments when it suited them, and conducted all the interviews herself.

Confirmability (neutrality or objectivity) implies congruence between two or more independent people about the data's accuracy, relevance or meaning, achieved through 'audit trails' (Stommel \& Wills 2004:288). Six groups of records were maintained to ensure an adequate audit trail:

- raw data (audio recordings, diaries, field notes)

- analysed data findings

- process of the study (strategies and procedures used)

- early intentions of the study (the proposal and expectations; instrument development information; data reconstruction products and drafts of the report).

Transferability refers to the extent to which the findings from one study can be applied to other settings or groups. Data with thick descriptions are available that can be used by authorised researchers in different settings and/or to crosscheck information provided in the research report (Stommel \& Wills 2004:288-289).

\section{Results}

\section{Biographic information}

Out of 22 interviewees, 90.9\% $(n=20)$ were females and their nursing experience ranged from 8 to 20 years, but $31.8 \%(n=7)$ had more than 20 years' experience. The unit managers' ages ranged from 31 to 50 . The 22 interviewed unit managers indicated that their CPR training included:

- formal CPR training during their basic nursing courses $(45.5 \% ; n=10)$

- basic CPR training $(22.7 \% ; n=5)$

- advanced CPR training and $(18.2 \% ; n=4)$

- varying amounts of CPR in-service training $(40.9 \% ; n=9)$.

Reportedly, only one unit manager had never performed CPR, one $(4.5 \%)$ performed CPR on a daily basis, and seven (31.8\%) performed CPR weekly, while eight (36.4\%) did so annually.

\section{Nurses managers' perceptions about nurses' CPR competencies}

Only one unit manager said CPR training was always provided to novice nurses in his/her unit. The responses from the 22 participants showed that they regarded:

- 'few' registered nurses as being CPR competent (36.4\%; $n=8)$

- only 'some' nurses as being sufficiently CPR competent $(54.5 \% ; n=12)$

- 'all' nurses to be competent to perform CPR $(4.5 \% ; n=1)$.

\section{Unit managers' perceptions about CPR-related issues}

Only $12(54.5 \%)$ unit managers 'frequently' or 'always' received team support during CPR situations. Most unit 
managers $(72.7 \% ; n=16)$ could not name the resuscitation guidelines used in their hospitals, but some referred to the guidelines from South Africa, the United States of America or the United Kingdom.

All 22 unit managers agreed that it was important to document CPR events in order to improve the quality of CPR interventions and that it was imperative for nurses to receive regular CPR training and to attend seminars to help them cope with death, dying and grieving.

\section{Qualitative data analysis: unit managers perceived CPR challenges}

Two major categories emerged from the analysis of the responses to the semi-structured questions, namely organisational factors that influence CPR performance (comprising 7 subcategories) and nurses' CPR training and development needs (with 5 subcategories). See Table 1.

\section{Category 1: Organisational factors influencing CPR performance}

Shortage of nurses and doctors: The shortage of nurses and doctors delays the inception of CPR, causes excessive workloads and increases nurses' stress levels during critical situations, as indicated by the following responses:

'Night duty only two nurses work ... During the resuscitation one will be resuscitating the patient alone. The other one will call the doctor ... Doctors are not there always since there is a shortage and sometimes one doctor covers the hospital. Nurses panic and doctors are not experienced.' (Participant 10)

'Sometimes we nurse 70 patients and only two nurses will be available during that shift. When we have resuscitation it is very difficult to do justice to our job mainly due to the shortage ...' (Participant 1)

Absence of resuscitation teams: The reported shortage of staff might have contributed to the absence of resuscitation teams in both hospitals, and this impacted negatively on CPR performance according to the unit managers:

'The most important person is doctor and he should be there to take decisions. But they take time to come ...' (Participant 9)

'You are stuck and end up doing the resuscitation. Getting the doctor during the resuscitation is very difficult.' (Participant 3)

'Nurses are not sure what to do during emergency. Even some doctors don't know what to check and how to act during an emergency ...' (Participant 6)

TABLE 1: Unit managers' perceived cardio-pulmonary resuscitation challenges: Categories and subcategories.

\begin{tabular}{ll}
\hline $\begin{array}{l}\text { Organisational challenges influencing } \\
\text { CPR performance }\end{array}$ & Nurses' training and development needs \\
\hline $\begin{array}{l}\text { Shortage of nurses and doctors } \\
\text { Absence of resuscitation teams }\end{array}$ & $\begin{array}{l}\text { Lack of CPR knowledge and skill } \\
\text { Lack of in-service CPR training } \\
\text { (simulation, computer assisted learning) }\end{array}$ \\
Communication problems & $\begin{array}{l}\text { Lack of in-service CPR training } \\
\text { (simulation, computer assisted learning) }\end{array}$ \\
\hline Doctors' attitudes & $\begin{array}{l}\text { Lack of in-service CPR training } \\
\text { (simulation, computer assisted learning) }\end{array}$ \\
Supplies and equipment & Annual mandatory CPR certification \\
Inadequate space to perform CPR & $\begin{array}{l}\text { Botswana's Nursing and Midwifery } \\
\text { Council }\end{array}$ \\
Non-existing CPR policies and guidelines & Lack of debriefing \\
\hline CPR, cardio-pulmonary resuscitation. &
\end{tabular}

The participants indicated that a resuscitation team, including an anaesthetist, a surgeon, a physician and a critical care trained nurse, would be able to meet the CPR challenges in their units, but no such teams existed.

Communication problems: Valuable time is wasted when a nurse has to summon a doctor or another qualified CPR provider. The participants expressed concerns about the hospitals' communication problems:

'Sometimes if you bleep the doctor or anaesthetist, you can't reach them.' (Participant 5)

'In ICU, no doctors sleep. Calling the doctor from home takes time ... Our bleeps most of the time do not work.' (Participant 7)

Doctors' attitudes: All situations requiring CPR interventions are stressful, with life-and-death consequences. The unit managers did not perceive the doctors to be confident during $\mathrm{CPR}$ interventions, as they commented:

'Some doctors respond very sluggishly and shy away from the participation.' (Participant 2)

'Doctors are reluctant to perform CPR on chronically ill patients.' (Participant 4)

'Some doctors don't know anything. That is why they have an attitude. They also need education on CPR.' (Participant 12)

Supplies and equipment: The following responses reveal the unit managers' perceived challenges concerning CPR equipment and drugs:

'Nurses run around, looking for ambu bags and waste time. Emergency trolley is not equipped well. Shortage of equipment and drugs forms a barrier ... Defibrillator not all of them can operate. Doctors don't know how to operate defibrillator ...' (Participant 21)

'Most of the time our emergency trolley is empty and we don't have drugs ...' 'Pharmacy does not know anything. Drugs are not available ...' (Participant 3)

'In our ward, no proper resuscitation trolley. Very old and it is falling apart.' (Participant 2)

'In our ward there is no (resuscitation) board. So compressions are not successful. Oxygen outlets are off.' (Participant 5)

Inadequate space to perform CPR: Inadequate space was regarded as a barrier by some participants. This could be attributed to overpopulation of the hospital wards. 'Floor beds' refer to patients lying on mattresses on the unit's floor when all the beds are occupied. Patients lying on the floors make it difficult to get equipment to any patient to perform $\mathrm{CPR}$, as explained by some participants:

'In A\&E [accident and emergency units], spacing in the unit is a problem. Congestion and spacing and we expect somebody to function at the fullest capacity ...' (Participant 8)

'In our ward patients are on the floor so we can't move the victim. Space is inadequate and mobility is affected during resuscitation.' (Participant 19)

'Sometimes in the ward floor beds limit adequate space to provide CPR.' (Participant 18)

Non-existing CPR policies and guidelines: The nurse mangers confirmed that standardised CPR policies did not 
exist in their hospitals, as became evident from the following comments:

'When I am providing CPR, I use ambu bag but we are not allowed to use drugs.' (Participant 22)

'No policy to guide us as nurses. If something goes wrong, we are responsible. But we end up giving some of the drugs if the patient needs to be resuscitated according to the situation.' (Participant 16)

Some participants expressed definite needs for CPR guidelines by stating:

'Nobody knows about the guidelines and don't follow the guidelines. Haphazard way of doing things during resuscitation and some are confused, panic and don't know what to do.' (Participant 11)

'We don't have guidelines to say what to do during resuscitation. Nurses' role is limited ... Oxygen and hydrocortisone are given by the nurse. Adrenaline and atropine are given by the doctors ...' (Participant 9)

'Most of us don't know how to attend the emergency since there are no guidelines ... At the time of resuscitation everybody is concerned about saving the life. Sometimes you even forget to wear gloves and [there is] so much risk involved during resuscitation.' (Participant 14)

'Things are not well in place. No standards and different approach. Each one will approach it in a different way. Structures are not explicitly stated. Different schools of thoughts so no standards ...' (Participant 1)

The unit managers encountered ethical dilemmas because of the absence of a 'do not resuscitate' policy in their hospitals, as indicated by the following responses:

'We don't have a policy on this. Terminally ill - you should come up with your own discretion ...' (Participant 7)

'Policy should be defined well [about] whom to resuscitate and whom not. No policy available for a medico-legal approach. Verbal actions and words are not safe and will not protect us from legal problems.' (Participant 9)

'We need to have a policy on resuscitating HIV/AIDS clients.' (Participant 5)

\section{Training-related challenges CPR competence}

The unit managers indicated that most nurses and doctors lacked CPR knowledge and skills when they stated:

'They lack knowledge and don't know the equipment on the emergency trolley ...' (Participant 3)

'A lot of doctors and nurses can't recognise cardiac arrest on time. '(Participant 6)

'Nurses and doctors are confused. No co-ordination and confusion since they lack knowledge.' (Participant 14)

Lack of in-service CPR training: Sustained education is indispensable for maintaining CPR knowledge and competence. The unit managers indicated that there were no permanent in-service CPR training programmes in their hospitals, when they stated:

'In our unit we never had any CPR in-service for the past year ... The reasons for that are shortages of manpower. Nurses are overworked and overwhelmed by the work ... So nobody shows interest for unit in-service ...' (Participant 22)

'Three years back I was taught about CPR. After the school I didn't have exposure.' (Participant 15)

'All nurses have to be taught CPR regardless of the area of work and regular in-service should be conducted. A nurse educator should be in charge of continuous education ...' (Participant 13)

'Nurse managers should take continuous education seriously...' (Participant 9)

The unit managers indicated that no CPR simulations or mock drills had been conducted in either hospital with the following responses:

'Simulation ... I have never seen one ... No simulation on CPR conducted ...' (Participant 21)

Some participants suggested that the creation of a dedicated hospital website from which nurses would be able to access all the information they need, would be valuable, by stating:

'Computer learning should be available on the hospital website so that they can practise at their own convenience... We will learn more [with] ... video tapes and CDs.' (Participant 20)

Annual mandatory CPR certification: All unit managers believed that annual mandatory CPR certification would help to enhance nurses' CPR competencies:

'Nurses learn CPR at school. But there is no practice afterwards. If it is mandatory, everybody will have the same knowledge and skills ...' (Participant 8)

'It helps the nurses to function independently during the absence of doctors ... It will help to improve our competency and help us to know the correct way it is being done.' (Participant 10)

'Many nurses in my unit can't function independently since they are not exposed to CPR frequently. So nurses are not confident and competent. They rely on managers. But some managers also don't have exposure.' (Participant 1)

The role of Botswana's Nursing and Midwifery Council: The absence of accredited standards hampered CPR performances, as indicated by the unit managers' comments:

'Every professional should have the BLS [basic life support] certificate.' (Participant 2)

'Nursing council should include BLS in their scope of practice. It helps nurses to get adequate exposure and also increase uniformity.' (Participant 15)

'I have done CPR long before. I don't have practice afterwards ...' (Participant 1)

‘Nursing Council manuals from Botswana are incomplete ... Most of us are not taught about CPR. I once saw it in the male medical ward.' (Participant 10)

Debriefing: Participants regarded debriefing after CPR procedures as being important by stating:

'It is important to give feedback so they know their strengths and weaknesses. But we don't do it ...' (Participant 7)

'Yes, I believe in debriefing. It helps to correct our mistakes ...' (Participant 5)

'If CPR is successful or unsuccessful, we should know the reasons ... Helps to assess and prepare us to deliver CPR effectively ...' (Participant 14) 
'Debriefing helps to close the gap. Debriefing helps to relieve guilty feelings and ease our emotions.' (Participant 21)

\section{Discussion of the research findings Organisational challenges}

The unit managers indicated that staff shortages caused excessive workloads, and might impact negatively on CPR interventions. Sometimes only two nurses had to care for 70 patients, leaving one nurse to render $\mathrm{CPR}$ interventions while the other one tries to call a doctor. Bucknall (2003:310) indicates that staff shortages affect decision making during critical situations. Nurses from Jordan maintained that staff shortages increased their workloads and stress-related symptoms (Hamaideh et al. 2008:40).

The unit managers' concerns about the absence of resuscitation teams in their hospitals and the problems of getting doctors to the CPR situations are supported by other researchers. According to Meerabeau and Page (1999:29), a competent team leader should be present to coordinate and manage all CPR incidents. The absence of expert leadership, and explicit distributions of tasks among team members can negatively affect the quality of CPR (Marsh et al. 2004:51). All hospitals should have CPR teams that can respond to emergencies (Gabbot et al. 2005:171).

Identified problems experienced by nurses because of inconsistent practices, attributable to the absence of resuscitation teams, included loss of valuable time during resuscitation, uncertainty about what to do, inefficient and inadequate CPR procedures and increased errors.

The unit managers' concerns about communication problems encountered during CPR situations have also been reported by other researchers. Gabbot et al. (2005:171) recommended that the members of a CPR team should be summoned by using one common dedicated telephone number. The lack of standardised communication procedures increases the probability of patient harm, the ineffective use and/or lack of resources and caregiver dissatisfaction (Leonard, Graham \& Bonacum 2004:i85).

In this study, the unit managers reported that doctors were uncertain about the resuscitation of chronically ill patients, took long to arrive at CPR scenes, and were unsure about CPR implementation. These attitudes aggravated nurses' uncertainty levels. Stress, fatigue, distractions and negative attitudes of health care providers during resuscitation may affect the CPR outcome (Leonard et al. 2004:i85).

The Resuscitation Council of the United Kingdom (2004:3) recommends that the hospital must ensure that the resuscitation team is activated within 30 seconds of a call for emergency help. The chances that CPR will be successful increase when resuscitation is provided within the first four minutes of arrest and when defibrillation is performed within eight minutes of the arrest (AHA 2005:1).
Unit managers' concerns about inadequate supplies and equipment to perform effective CPR interventions are supported by other researchers. Laws (2001:6) noted that unavailable and poor quality equipment influence patient outcomes and cause stress for the nurses. Kavari and Keshtkaran (2005:1) agree that with unavailable or malfunctioning equipment, the possibility of performing successful CPR becomes remote.

Unless nurses and doctors can reach the patient with an emergency trolley, no effective CPR can be performed. The unit managers reported the overpopulation of hospital wards, and especially patients lying on floors to be posing CPR challenges.

The nurse managers indicated that both hospitals lacked CPR policies, posing challenges for effective CPR implementation. Shuriquie, While and Fitzpatrick (2007:144) assert that the absence of clear guidelines affects nurses' CPR competence negatively, contributing to substandard practices. The Resuscitation Council of the United Kingdom (2004:4) recommends that resuscitation committees should ensure compliance with national resuscitation guidelines and standards. The absence of such guidelines creates a gap between the theory and practice of CPR (Desalu, Kushimo \& Akinlaja 2006:517).

Some unit managers indicated that CPR policies should address the:

- establishment and maintenance of a CPR team for each hospital

- roles and responsibilities of every team member to reduce role ambiguities

- protection of staff members during CPR procedures

- conflicts between doctors and nurses and

- sustained in-service CPR training.

Most participants felt that there should be no difference between resuscitating HIV / AIDS patients and other patients, provided universal precautions are followed. Although the actual risk of HIV transmission during mouth-to-mouth ventilation is very low, physicians and nurses might remain fearful of becoming infected with HIV (Oyeyemi, Oyeyeymi \& Bello 2008:11). Nurses in Africa face daily challenges when they need to make decisions requiring them to balance their own long-term safety needs against the immediate survival needs of their patients (Ehlers 2006:657).

\section{Training challenges}

The unit managers considered most nurses and some doctors to be incompetent in performing CPR. This situation is not unique to Botswana. Studies conducted in the UK, Iran and Ireland also identified deficiencies in nurses' CPR knowledge and skills (Madden 2006:218; Nikandish, et al. 2007:321).

The absence of ongoing CPR training in Botswana, affected nurses' CPR competence levels, according to the participants in this study. Verplancke et al. (2008:75) reported that nurses 
who did not attend CPR refresher courses for more than two years lacked CPR competence.

Although simulation and computer-based learning experiences were unavailable in Botswana, the unit managers indicated that these could be useful learning aids. Perkins (2007:202) agrees that simulation enables nurses to acquire the knowledge, attitudes and skills required in CPR situations in a systematic and confident manner.

Hanefeld et al. (2005:167) agree about the importance of a minimal standard of competence and that all staff should undertake mandatory training in basic life support and attend compulsory annual refresher training. The unit managers agreed that Botswana's Nursing and Midwifery Council should institute mandatory annual CPR relicensure, but sufficient training facilities offering such training need to established.

No debriefing sessions were conducted after CPR attempts. All unit managers agreed that there was an urgent need for debriefing sessions. Nurses might be adversely affected by stress and anxiety when they are confronted with the realities of grief, dying, death and loss without the necessary knowledge, skills and support to process their own emotions and offer help and comfort to the dying and to the families and friends of dying patients (Hinshaw 2002:565).

\section{Limitations}

Interviews were conducted with 22 unit managers from two referral public hospitals in Botswana. Other government and private hospitals might encounter different challenges. No observations were done about actual CPR interventions.

No interviews were conducted with doctors and other categories of nurses.

\section{Recommendations}

The findings of this study indicate a dire need to upgrade CPR supplies and resources as well as the training of nurses and doctors to enhance the outcomes of CPR interventions:

- Nurses' workloads should be realistic.

- Accurate records should be kept of all CPR interventions, actions taken by whom, the number of nurses on duty as well as the number of patients in the unit. This information might provide factual data for the realistic future assignment of nurses to specific hospital units.

- Shortcomings of emergency trolleys in all hospital units must be addressed.

- Every hospital should have a resuscitation team with specific tasks assigned to each member. These team members' telephone numbers must be available in all hospital units. Every hospital unit's designated emergency co-ordinator should assume responsibility for co-ordinating CPR activities until the resuscitation team arrives.
- All nurses' and doctors' bleepers must be in working order. Ideally, one doctor should be available on the hospital premises at all times and his/her cellular phone number should be available in all hospital units.

- Patients recovering from major surgery and/or car accidents should be kept in sections where 'floor beds' are not allowed so that patients can be reached to implement CPR procedures.

- CPR policies and guidelines should address the resuscitation of terminally ill and AIDS patients, when CPR should not be implemented and when CPR should be stopped.

- Debriefing services should be provided after CPR interventions.

- Effective CPR in-service education should be provided, including simulation and computer-based learning experiences. (Since the completion of this study the University of Botswana has instituted a 'Resuscitation training project' for medical and nursing students as well as for registered nurses). Mandatory annual CPR certification should be considered by the Botswana Nursing and Midwifery Council.

\section{Conclusion}

Organisational challenges that influenced CPR outcomes included staff shortages causing heavy workloads, inadequate and non-functional equipment, absence of resuscitation teams, doctors' negative attitudes, communication problems, inadequate space to perform CPR, non-existing CPR policies and guidelines, and inadequate in-service CPR training. Unless nurses and doctors have access to fully functional equipment and the necessary drugs, and operate according to specific written policies and guidelines, they are unlikely to save many lives by performing CPR, irrespective of their individual levels of expertise. Unless the identified shortcomings are addressed, lives might be lost due to ineffective CPR performance in Botswana's major referral hospitals.

\section{Acknowledgements}

We express our gratitude to all authorities, persons and institutions who granted permission for this study to be conducted. The contribution of every unit manager who participated in the interviews is gratefully acknowledged.

\section{Competing interests}

The authors declare that they have no financial or or personal relationships which might have influenced them inappropriately in writing this paper.

\section{Authors' contributions}

L.R. was the project leader. L.R. and V.J.E. participated jointly in the conceptualisation and design of the study. L.R. collected the data. L.R. and V.J.E. analysed the data and wrote the manuscript. 


\section{References}

American Heart Association., 2005, 'Guidelines for cardiopulmonary resuscitation and emergency cardiovascular care', Circulation 112-IV-206-IV-211.

Bucknall, T., 2003, 'The clinical landscape of critical care: Nurses' decision making', Journal of Advanced Nursing 43(3), 310-19. http://dx.doi.org/10.1046/j.1365 2648.2003.02714.x, PMid:12859790

Cresswell, J.W., 2003, Research design: Qualitative, quantitative and mixed methods approaches, Sage, London.

Davies, N. \& Gould, D., 2000, 'Upgrading cardiopulmonary resuscitation skills: A study to examine the efficacy of self-instruction on nurses' competence Journal of Clinical Nursing 9(3), 400-410. http://dx.doi.org/10.1046/j.13652702.2000.00389.x, PMid:11235315

Desalu, I., Kushimo, O. \& Akinlaja, O., 2006, 'Adherence to CPR guidelines during perioperative cardiac arrest in a developing country', Resuscitation 69(3), 517-520. http://dx.doi.org/10.1016/j.resuscitation.2005.10.012, PMid:16563595

Ehlers, V.J., 2006, 'Challenges nurses face in coping with the HIV/AIDS pandemic in Africa', International Journal of Nursing Studies 43(6), 657-662. http://dx.doi. org/10.1016/j.ijnurstu.2005.11.009, PMid:16436278

Hamaideh, S.H., Mrayyan, M.T., Mudallal, R., Faouri, I.G. \& Kshsawneh, N.A., 2008, 'Jordanian nurses' job stressors and social support', International Nursing Review 55(1), 40-47. http://dx.doi.org/10.1111/j.1466-7657.2007.00605.x PMid:18275534

Handley, I.J., Koster, R., Monseieur, K., Perkins, G.D., Davies, S. \& Bossaert, L., 2005 'European Resuscitation Council guidelines for resuscitation, adult basic life support and use of automated external defibrillators', Resuscitation 67S1, S7-S23.

Hinshaw, D.B., 2002, 'The spiritual needs of the dying patient', Journal of the American College of Surgeons 195(4), 565-568. http://dx.doi.org/10.1016/S1072 7515(02)01328-5

Kavari, H.S. \& Keshtkaran, A., 2005, 'The comparison of nurses' individual problems in CCU and emergency wards', Middle East Journal of Family Medicine 3(2), 1-4.

Laws, T., 2001, 'Examining critical care nurses' critical incident stress after in hospital cardiopulmonary resuscitation', Australian Critical Care 14(2), 76-81. http:// dx.doi.org/10.1016/S1036-7314(01)80010-2

Leonard, M., Graham, S. \& Bonacum, S., 2004, 'The human factor: The critical importance of effective teamwork and communication in providing safe care' Quality and Safety in Health Care 13(1), i85-i90. http://dx.doi.org/10.1136/ qshc.2004.010033, PMid:15465961, PMCid:1765783

Lincoln,Y.S. \& Guba, E.G., 1985, Naturalistic inquiry, Sage, Beverly Hills.
Madden, C., 2006, 'Undergraduate nursing students' acquisition and retention of CPR knowledge and skills', Nurse Education Today 26(3), 218-227. http://dx.doi. org/10.1016/j.nedt.2005.10.003, PMid:16314002

Meerabeau, L. \& Page, S., 1999, 'I'm sorry if I panicked you: Nurses' accounts of teamwork in cardiopulmonary resusictation', Journal of Inter Professional Care' 13(1), 29-40. http://dx.doi.org/10.3109/13561829909025533

Nikandish, R., Jamshidi, H., Musavifard, R., Zebardast, T. \& Habibi, N., 2007, 'Basic cardiopulmonary resusictation skills in nurses at teaching hospital in Southeast Irab in 2006', Resuscitation 73(2), n321-322. http://dx.doi.org/10.1016/j. resuscitation.2006.12.016, PMid:17343973

Oyeyemi, A.Y., Oyeyemi, B.O. \& Bello, I.S., 2008, 'AIDS care in Nigeria: Are nurses comfortable performing procedures?', International Journal of Nursing Practice 14(1), 11-18. http://dx.doi.org/10.1111/j.1440-172X.2007.00668.x PMid:18190479

Page, S. \& Meerabeau, L., 1996, 'Nurses' accounts of cardiopulmonary resuscitation' Journal of Advanced Nursing 24(2), 317-323. http://dx.doi.org/10.1046/j.13652648.1996.18413.x, PMid:8858436

Perkins, D.G., 2007, 'Simulation in resusictation training', Resuscitation 73(2), 202211. http://dx.doi.org/10.1016/j.resuscitation.2007.01.005, PMid:17379380

Pottle, A. \& Brant, S., 2000, 'Does resuscitation training affect outcome from cardiac arrest?', Accident and Emergency Nursing 8(1), 46-51. http://dx.doi.org/10.1054/ aaen.1999.0089, PMid:11147020

Republic of Botswana, 2006, Health Statistics Report, Ministry of Health, Gaborone, Government Printer.

Republic of Botswana, 2010, Master Health Facility Report, Ministry of Health Gaborone, Government Printer.

Resuscitation Council of the United Kingdom, 2004, Recommended equipment for in hospital resuscitation, viewed 17 January 2006, from www.resus.org.uk/pages/ equipIHAR/htm

Stommel, M. \& Wills, C.E., 2004, Clinical research: Concepts and principles for advanced practice nurses, Lippincott, Williams \& Wilkins, Philadelphia.

Shuriquie, M., While, A. \& Fitzpatrick, J., 2007, 'The development of role adequacy for professional nurses in Jordan', International Nursing Review 54(2), 144-150. http://dx.doi.org/10.1111/j.1466-7657.2007.00563.x, PMid:17492987

Verplancke, T., Paepe, P.D., Calle, P.A., Regge, M.D., Maele, G. \& Monseiurs, K.G. 2008, 'Determinants of the quality of basic life support by hospital nurses', Resuscitation 77(1), 75-80. http://dx.doi.org/10.1016/j.resuscitation.2007.10.006, PMid:18083286 